\title{
EUROPEAN AND INTERNATIONAL LAW AND PALESTINIAN REFUGEES: BOLBOL, EL KOTT AND THE APPLICATION OF ARTICLE 1D OF THE GENEVA CONVENTION
}

\author{
Marguerite Perin*
}

\begin{abstract}
This paper explores the recent Court of Justice of the European Union (CJEU) judgments of $\mathrm{El} \mathrm{Kott}$ and Bolbol, and the implications of those judgments on the interpretation and application of Article 1D. In the first part, I seek to give a brief overview of the purpose of Article 1D, as regards the Palestinian refugee population. I then go on to look at the interpretations adopted in the Bolbol and El Kott judgments of the CJEU. In the final part of this paper, I explore the difficulties of assessing indiscriminate violence in light of the CJEU judgments, by referring to the stance adopted by other international and national courts. In particular, I establish that requiring an individualisation of the risk goes against the purpose of Article 1D.
\end{abstract}

\section{A. INTRODUCTION}

The coming into force of the Qualification Directive of 29 April $2004^{1}$ has enabled the Court of Justice of the European Union (CJEU) to indirectly interpret provisions of the Geneva Convention relating to the status of refugees. The specific status contained in Article 1D of the Geneva Convention, catering for the Palestinian refugee problem, is one of the provisions that the CJEU has had the opportunity to clarify. In a series of significant cases, namely Bolbol, ${ }^{2}$ and more recently, El Kott, ${ }^{3}$ the CJEU has sought to refine the interpretation of Article 1D of the Geneva Convention. In Bolbol, the Court clarified the requirement of availment of protection and assistance by the agencies of the United Nations. In El Kott, the Court looked to the personal safety of refugees in the context of refugee camp violence, as a basis for departure from their country of habitual residence. Whilst the CJEU's judgments could have enabled a harmonious interpretation and application of Article 1D across Member States, it is submitted that in applying them, national courts will seek to restrict refugee flows,

\footnotetext{
* Law and French Law LLB and International Law LLM, University College London. The author would like to thank Ruth Kennedy and Touria Lebbad for their comments on earlier drafts of this paper.

${ }^{1}$ Council Directive 2004/83/EC of 29 April 2004 on minimum standards for the qualification and status of third country nationals or stateless persons as refugees or as persons who otherwise need international protection and the content of the protection granted [2004] OJ L304/12.

${ }^{2}$ Case C-31/09 Nawras Bolbol v Bevándorlási és Állampolgársági Hivatal [2010] ECR I-05539.

${ }^{3}$ Case C-364/11 Mostafa Abed El Karem El Kott, Chadi Amin A Radi, Hazem Kamel Ismail v Bevándorlási és Állampolgársági Hivatal [2012] (Grand Chamber, 19 December 2012).
} 


\section{European and International Law and Palestinian Refugees: Bolbol, El Kott and the Application of Article $1 D$ of the Geneva Convention}

thereby developing restrictive tests. In their application of the judgments, courts of Member States will rely on the mechanisms that they have already developed to appreciate a context of generalised and indiscriminate violence. The first part of this paper will lay down the nature and purpose of Article 1D of the Geneva Convention, as well as identify the key challenges entailed by the creation of a specific refugee status. The second part will seek to analyse the Bolbol and El Kott judgments and what additions they have brought to the interpretation of article 1D. The last part will seek to anticipate how a risk assessment can be carried out, in applying the most recent CJEU case law. It is submitted that in doing this, mechanisms for the appreciation of indiscriminate violence already developed in the context of subsidiary protection can prove useful.

\section{B. THE GENEVA CONVENTION AND CREATION OF A SEPARATE REFUGEE STATUS}

The 1951 Geneva Convention relating to the Status of Refugees is the "cornerstone of the international legal regime for the protection of refugees", ${ }^{4}$ as reiterated by the CJEU. Its drafting and conclusion brought about several key changes in refugee law, as identified by Akram. ${ }^{5}$ Its most prominent innovation is the change from a group notion of refugees, to an individualised notion of refugees. The criteria to be met in order to benefit from refugee status under the Convention, set out in Article 1A, second paragraph, show the case-by-case approach that Akram mentions. However, Akram notes that Article 1D does not reflect this approach, as the provision creates a separate category, grouping Palestinian refugees together. ${ }^{6}$

Article 1D of the Geneva Convention provides for a specific and separate status for "persons who are at present receiving from organs or agencies of the United Nations other than the United Nations High Commissioner for Refugees protection or assistance". A corresponding provision is found in the United Nations High Commissioner for Refugees (UNHCR) Statute, at paragraph 7(c), in which it is specified that refugees receiving protection or assistance from other UN organs are not included in the UNHCR mandate. ${ }^{7}$

\footnotetext{
4 ibid, para 42.

${ }^{5}$ Susan M Akram, 'Palestinian Refugees and Their Legal Status: Rights, Politics and Implications for a Just Solution’ (2002) 31 Journal of Palestine Studies 36.

6 ibid, 40.

${ }^{7}$ UN General Assembly, Statute of the Office of the United Nations High Commissioner for Refugees UN General Assembly Resolution (UNGAR) 428(V) (14 December 1950).
} 
The provision was drafted, and has evolved, in a factual and very politically charged setting. The UN's implication in the establishment of the state of Israel, resulting in the creation of the Palestinian refugee population, spurred the drafters to address this particular issue in the Geneva Convention. The text of Article 1D was proposed by Arab states, including Egypt, Lebanon and Saudi Arabia. Singh explains that, whilst others had become refugees in situations which went against the general principles of the UN, the Palestinian refugee population was created as a direct consequence of the UN's actions. ${ }^{8}$ A statement from the Arab states during the negotiations sums up this view: "[t]he Palestine refugees were therefore a direct responsibility on the part of the United Nations and could not be placed in the general category of refugees without betrayal of that responsibility." 9 Furthermore, European signatories were wary of a potential mass influx of Palestinians seeking asylum in their territory, showing reluctance, as highlighted by the statements issued during drafting, to "bind themselves to a text under which their obligations would be extended to include a new, large group of refugees". ${ }^{10}$ As a result of these concerns, the Geneva Convention separates the Palestinian refugee population from the rest. This is also compatible with the search for a durable, long-term solution for the Palestinian refugee population. Thus, whilst they do not mention Palestinians explicitly, the travaux préparatoires show that the provision was clearly drafted with this particular population in mind, as made clear by the statements above.

Article 1D is thus a parallel status, as it excludes those receiving protection and assistance from a UN Agency from qualifying for refugee status under Article 1A(2) of the Geneva Convention. The importance of its interpretation is emphasised when looking at the number of persons concerned by the provision. A recent paper states that at the end of 2008, there were 6.6 million Palestinian refugees, which represents $67 \%$ of the total Palestinian population - although numbers are approximate, as there is no central registration system. ${ }^{11}$ More recent figures published by UNRWA show that, as of July 2013, the total number of Palestinian refugees registered with UNRWA was 4.9 million. ${ }^{12}$

The European framework of legislation, which complements the Geneva Convention, is contained in Directive 2004/83/EC, the Qualification Directive. It has since been recast by

\footnotetext{
${ }^{8}$ Anne Singh, 'Stateless Palestinians and the Refugee Convention' [2009] ILPA 1.

${ }^{9}$ Statement of Mr Azkoul (Lebanon) (27 November 1950) 5 UNGAOR 358.

${ }^{10}$ Statement of Mr Rochefort (France) (26 November 1951) UN Doc A/CONF.2/SR.19 11.

${ }^{11}$ BADIL, Survey of Palestinian Refugees and IDPs Summary of Findings (2008)

<http://www.badil.org/phocadownload/Badil_docs/publications/survey08-09/survey08-09-executivesummary.pdf $>$ accessed 12 May 2014.

${ }^{12}$ UNWRA, UNWRA in Figures (UNWRA, July 2013)

<www.unrwa.org/sites/default/files/unrwa_in_figures_new2014_10nov2014.pdf> accessed 7 May 2014.
} 


\section{European and International Law and Palestinian Refugees: Bolbol, El Kott and the Application of Article $1 D$ of the Geneva Convention}

Directive 2011/95/EU. Whilst the recast Directive introduced some changes, they mostly related to the rights and benefits of refugees and those granted subsidiary protection, rather than addressing the granting of refugee status. As such, none are pertinent to the present analysis. The 2004 Directive contains language similar to the Convention, with Article 12(1)(a) of the Directive excluding from its scope any person coming within Article 1D of the Convention. It is after the adoption of the Directive that the Court of Justice of the European Union was given the opportunity to interpret, albeit indirectly, the wording of the Refugee Convention. This led to high expectations, as the Court's new competence was expected to lead to a harmonisation of asylum policy across Europe. ${ }^{13}$

The nature of Article 1D has been the topic of debate. Article 1D is referred to as an "exclusion" clause in the UNHCR Handbook, as it excludes a certain population from the application of the Geneva Convention. ${ }^{14}$ Takkenberg points out that the intention of the drafters was simply to exclude Palestinian Refugees temporarily, until a long-term solution was found. ${ }^{15} \mathrm{He}$ goes on to argue that the wording of the article leaves much to be desired in terms of clarity: "[i]t does not seem logical to include conditionally a whole category of refugees, similar to article 1a, paragraph 1, by way of an exception to an exclusion clause!"16 Grahl-Madsen presents a similar argument, and takes the view that it is a suspensive, rather than exclusory, clause. ${ }^{17}$ The view that Article $1 \mathrm{D}$ constitutes only a temporary exclusion clause is convincing. It is plainly reflected in the language of the provision. Whilst the first sentence has an exclusionary effect, the wording of the second sentence of Article 1D and its use of the phrase "ipso facto" suggests that it is in fact a temporary exclusion, as it provides for the inclusion of the concerned population, should the basis for the exclusion (receipt of protection and assistance from UN agencies) cease to exist. The final effect of the provision is that once the grounds for exclusion cease to exist the Convention is applicable to Palestinian refugees. In this way, it is a provision which aims to ensure the continuity of protection of Palestinian refugees, in accordance with the object and purpose of the Geneva Convention. It is meant to ensure that the concerned population benefits from heightened international protection. At the time of the drafting of the Convention, it was envisaged that Article 1D should serve as a temporary solution until a more durable one was found for

\footnotetext{
${ }^{13}$ BADIL, Closing Protection Gaps: A Handbook on Protection of Palestinian Refugees in States Signatories to the 1951 Refugee Convention. Jurisprudence Regarding Article 1D 2005-2010 (2nd edn, BADIL 2011) 17.

${ }^{14}$ UNHCR, Handbook on Procedures and Criteria for Determining Refugee Status under the 1951 Convention and the 1967 Protocol relating to the Status of Refugees (UNHCR 1992).

${ }^{15}$ Alex Takkenberg, The Status of Palestinian Refugees in International Law (OUP 1998) 93.

16 ibid.

${ }^{17}$ Atle Grahl-Madsen, The Status of Refugees in International Law (AW Sijthoff 1966) 263.
} 
Palestinian refugees, as seen in the language used by the UN General Assembly, which envisaged that relief as provided by UN agencies should terminate no later than December 1950. ${ }^{18}$ Broader questions about the justifications for the creation of a separate refugee status have also been raised. Kagan in particular has questioned whether the Palestinian exceptionalism still has standing today. ${ }^{19} \mathrm{He}$ argues that the UN responsibility theory - the idea that the UN bears responsibility for the creation of the Palestinian refugee population greatly overstates the organisation's participation, which he identifies as being limited to the failure to provide peaceful resolution of a conflict. Combined with the expanding of the United Nations Relief and Works Agency (UNRWA) mandate to resemble that of the UNHCR, he goes on to demonstrate how he considers the separate status for Palestinian refugees obsolete. Whilst an analysis of his argument is outside the scope of this paper, it provides a useful insight into the objections raised against the creation of Article 1D.

\section{THE CJEU'S INTERPRETATION OF ARTICLE 1D}

The interpretation of Article 1D has been centred around two points of particular importance. The first issue is whether, once the protection and assistance mentioned in Article 1D has ceased, refugees should automatically benefit from protection under Article 1A(2) of the Convention, or whether they should have to meet additional requirements. The second point of contention is determining the conditions to be met in order for an Article 1D status to cease. Whilst the language used ("for any reason") suggests a broad approach to this question, the exact parameters are difficult to pinpoint. The recent Bolbol and El Kott judgments of the Court of Justice have shed some light on both questions.

\section{Interpretation of "Ipso Facto" and Automatic Refugee Status}

A key question, when looking at the application of Article 1D, is whether, once the grounds for exclusion mentioned in the provision cease to exist, refugee status is automatically obtained, along with the benefit of the rights contained in the Geneva Convention, or whether a person in question also needs to meet the additional requirements set out in Article $1 \mathrm{~A}(2)$. The requirements contained in the latter include a well-founded fear of persecution, for reasons of one of the five convention grounds (race, religion, nationality, membership of a particular social group, political opinion), as well as being unwilling or unable to avail

\footnotetext{
${ }^{18}$ United Nations General Assembly, Resolution 302 (8 December 1949) (UNGAR 302).

${ }^{19}$ Michael Kagan, 'The (Relative) Decline of Palestinian Exceptionalism and its Consequences for Refugee Studies in the Middle East' (2009) 22 Journal of Refugee Studies 417.
} 


\section{European and International Law and Palestinian Refugees: Bolbol, El Kott and the Application of Article $1 D$ of the Geneva Convention}

themselves of the protection of the country of residence. By creating a unique legal status, the drafters recognised the precarious and unique situation of Palestinian refugees. Inherent in such reasoning is the idea that Article $1 \mathrm{~A}(2)$ is inadequate to their situation. In practice, they are unlikely to be successful in meeting such requirements. The very use of the phrase "ipso facto" in the language of Article 1D seems to indicate that refugee status should be acquired automatically upon cessation. Therefore, the prior recognition of Palestinian refugees as refugees by the international community seems to suggest there should be no additional requirements to be met. This interpretation of the provision was adopted by the UNHCR. ${ }^{20}$

In the case law prior to $E l K o t t$, the tendency of courts to balance this favourable reading of ipso facto with a restricted scope of Article 1D was apparent. This can be illustrated by reference to the El-Ali case from 2002, from the UK Court of Appeal. ${ }^{21}$ In the judgment, the Court of Appeal confirms that the term "ipso facto" indicates that Palestinian refugees benefit from an automatic refugee status upon cessation of protection and assistance. ${ }^{22}$ However, the Court of Appeal considered that this only applies to those who qualified as Palestinian refugees on or before the $28^{\text {th }}$ July 1951, at the time of signature of the Geneva Convention. The reasoning put forward to support this argument is that "so great a parcel of rights" ${ }^{23}$ should not be granted without the category of recipients being precisely defined. Those who were not recognised as refugees at the time of drafting must have their applications examined individually, on a case-by-case basis, before they can be granted refugee status, provided they meet the criteria set out in Article 1A(2). Professor GoodwinGill, who made an intervention in this case on behalf of the UNHCR, convincingly argued that the Convention had a continuative effect thus encompassing those that had become refugees even after $1951 .{ }^{24}$ Interpreting the Convention in any other way would lead to an artificial distinction, as identified by Takkenberg. ${ }^{25} \mathrm{He}$ also refers to a judgment of the German Federal Administrative Court of 1991, in which it is held that

"a different interpretation would lead to the inappropriate, apparently unintended result that persons enjoying protection or assistance after the set date, for example

\footnotetext{
${ }^{20}$ UNHCR, Revised Note on the Applicability of Article 1D of the 1951 Convention relating to the Status of Refugees to Palestinian Refugees (UNHCR 2009).

${ }^{21}$ Amer Muhammad El-Ali v The Secretary of State for the Home Department [2002] EWCA Civ. 1103.

22 ibid, para 49.

${ }^{23}$ ibid, para 50.

24 ibid, para 33.

${ }^{25}$ Takkenberg (n15) 98.
} 
descendants born later, would be treated differently under the 1951 Convention, although they share the same refugee experience." 26

The Bolbol case, decided by the Court of Justice of the European Union, was silent on this matter, despite the fact that this point of interpretation was one of the questions posed to the Court. The subsequent $\mathrm{El} \mathrm{Kott}$ case sought to address the questions left unanswered by Bolbol. In El Kott, the Court was once more asked whether the language of the Directive, which mentions in Article 11(1)(a) that a person is "entitled to the benefits of this Directive" following cessation of protection and assistance, should be interpreted so as to mean that the applicants should benefit from refugee status under the 1951 Convention, from subsidiary protection under the Qualification Directive, or neither. The Court very clearly took the position that the phrase "benefits of the Directive", or, as phrased in the Geneva Convention, "benefits of this Convention", meant more than simply the possibility of applying for refugee status under Article $1 \mathrm{~A}(2)$, as this was already an option. It goes on to consider that the second sentence of Article 1D would be "superfluous and ineffective" if its only purpose were to reiterate that persons who do not come within the exclusion clause may rely on the Convention itself. ${ }^{27}$ Whilst the Court recognised that, once cessation had occurred, such a right to refugee status existed, it is not an unconditional right. Thus, the applicant will have to prove that he or she has sought protection and assistance from a United Nations agency, that cessation has occurred, and that none of the exclusion grounds, as set out in Article $1 \mathrm{C}, 1 \mathrm{E}$ and $1 \mathrm{~F}$ of the Geneva Convention, apply. These include situations where the applicant reavails him of herself of a new nationality, acquires a new nationality, when the applicant has committed a war crime, a serious non-political crime, or acted in a manner which goes against the principle and purposes of the United Nations. However, applicants will not be required to satisfy the requirements set out in Article 1A(2). The Court of Justice seems to have reached a balance between on the one hand, ensuring that Palestinian refugees benefit from equal, if not higher, international protection, and on the other hand, ensuring that the criteria are not so broad as to create an influx of Palestinian refugees into the European Union. The Court was deliberately careful with this very sensitive topic.

Thus, it is clear from the case law preceding El Kott that the UK Court of Appeal was mostly uncomfortable with leaving the category wide open. The consequences of failing to adopt a restrictive notion of refugees comprise that any person concerned by the second sentence of Article 1D is automatically entitled to the rights in the Convention, without

\footnotetext{
${ }^{26}$ German Federal Administrative Court BVerG 1C 42.88 (4 June 1991).

${ }^{27}$ El Kott (n 3) para 73.
} 


\section{European and International Law and Palestinian Refugees: Bolbol, El Kott and the Application of Article 1D of the Geneva Convention}

having to satisfy the criteria of Article $1 \mathrm{~A}(2)$. This is seemingly what the courts may seek to avoid. In El-Ali, the Court of Appeal seemed to think it had struck a "proper balance" in defining a fixed class of refugees. ${ }^{28}$ However, it is submitted that a distinction between different generations of Palestinian refugees sets a dangerous precedent, and does not sit well with the apparent objectives of the Geneva Convention. Therefore, the interpretation of the wording by the CJEU in El Kott is a welcome confirmation of the ipso facto interpretation, the Court having not chosen to compromise, as the Court of Appeal did in the UK, by adopting a stricter understanding of the notion of refugee. Furthermore, the Court of Appeal's interpretation in El Ali was explicitly criticised in Bolbol, where the CJEU stated that

"contrary to the line of argument developed by the United Kingdom Government, it cannot be maintained, $[\ldots]$ that only those Palestinians who became refugees as a result of the 1948 conflict who were receiving protection or assistance from UNRWA at the time when the original version of the Geneva Convention was concluded in 1951 are covered by Article 1D of the convention." 29

\section{Protection and Assistance}

In order to benefit automatically from Convention refugee status, the applicant has to show that cessation of protection and assistance has occurred, and that they are thus no longer excluded from the application of the Geneva Convention under Article 1D.

\section{a) Context in which assistance and protection is provided}

Originally, two agencies were created for the purposes of providing the protection and assistance mentioned in Article 1D. The United Nations Relief and Works Agency (UNRWA), and the UN Conciliation Commission for Palestine (UNCCP) were established as the two pillars of the Article 1D regime. Their mandates were entrusted to them by the United Nations General Assembly. In Resolution 194 of the $11^{\text {th }}$ of December 1948, the General Assembly established the UNCCP, and instructed it "to take steps to assist the Governments and authorities concerned to achieve a final settlement of all questions outstanding between them." ${ }^{30}$ Following a failure to negotiate refugee repatriations with Israel, the UNCCP protection mandate was terminated by a series of UN General Assembly measures in 1952. Akram notes that the "UNCCP devolved from an agency charged with the "protection of the

\footnotetext{
${ }^{28}$ El-Ali (n 21) para 42.

${ }^{29}$ Bolbol (n 2) para 47.

${ }^{30}$ UN General Assembly, Resolution 194 (III) (11 December 1948) (UNGAR 194(III)).
} 
rights, property and interests of the refugees' to little more than a symbol of UN concern for the unresolved aspects of the Arab-Israeli conflict." ${ }^{31}$ UNRWA was given its initial mandate by a 1949 Security Council Resolution ${ }^{32}$, which stated that UNWRA was to provide "direct relief and works programmes" to Palestine refugees, as well as "consult with the Near Eastern governments concerning measures to be taken preparatory to the time when international assistance for relief and works projects is no longer available". The mandate was extended to include education in 1958. UNWRA's current mandate includes the provision of relief, human development and protection services to Palestine refugees. The General Assembly renews its mandate regularly.

Qafisheh and Azarov suggest there are three different ways to interpret the terms of "protection or assistance" in light of the different mandates given to the agencies, for the purpose of interpreting Article 1D. ${ }^{33}$ In the wording of the Refugee Convention, the term of "protection" refers to the fulfilment of basic human rights and physical security - something which would usually be undertaken by the State for its citizens. The first is to consider that UNRWA was mandated to provide assistance to the Palestinian refugees, as well as the realisation of their basic rights, whilst UNCCP was entrusted with their protection - more specifically, finding a durable solution to their plight, as well as facilitating resettlement and return. This would mean that, once the UNCCP mandate was terminated by the General Assembly, that protection had ceased. Following this reasoning, and according to the second sentence of Article 1D, the grounds for the temporary exclusion ceased to exist, and the Convention from that point onwards was applicable to all Palestinian refugees. The second interpretation is to consider that there is no distinction to be made between protection and assistance. They are indissociable, and not attributed to separate agencies. They are simply used as synonyms, to designate the care provided by the United Nations. A quick look at the drafting history of the Convention shows that many terms were used interchangeably; such as "cared for" ${ }^{34}$, and "aid". ${ }^{35}$ The third interpretation is that, although the mandate of the UNCCP has not been renewed, UNRWA has undertaken the role of providing both protection and assistance. Its role is now sufficient to exclude the Palestinian refugees from the UNHCR mandate. This seems to be the more convincing interpretation.

\footnotetext{
${ }^{31}$ Susan M Akram, 'Reinterpreting Palestinian Refugee Rights under International Law, and a Framework for Durable Solutions' (2000) BADIL Information and Discussion Brief.

${ }^{32}$ UN Security Council, Resolution 302 (IV) (8 December 1949) (UNSCR 302(IV)).

${ }^{33}$ Mutaz Qafisheh and Valentina Azikov, 'Article 1D' in Andreas Zimmermann (ed), The 1951 Convention Relating to the Status of Refugees and its 1967 Protocol, a Commentary (OUP 2011).

${ }^{34}$ Statement of Mr Bey (Egypt) (3 December 1951) UN Doc A/CONF.2/SR.19, 16-17.

35 ibid.
} 


\section{European and International Law and Palestinian Refugees: Bolbol, El Kott and the Application of Article 1D of the Geneva Convention}

This last position has been criticised by Akram, who considers UNRWA to be ill suited to replace UNCCP, as it lacks the mandate and is poorly equipped to provide protection. ${ }^{36}$ Akram points out that there is a visible "Protection Gap", as Article 1D excludes from the UNHCR mandate Palestinian refugees who may not come within the ambit of the UNRWA mandate either, therefore lacking any international protection. This seems further aggravated by the limited UNHCR intervention, as well as insufficient protection mechanisms on the part of national authorities. Akram thus considers that the failure of UNCCP necessarily entails that all Palestinian refugees come within the scope of the Convention, as well as the UNHCR mandate. Kagan points to the wording of 1D to refute this argument. ${ }^{37}$ Article $1 \mathrm{D}$ excludes "persons who are at present receiving [...] protection or assistance". The wording used suggests that either protection or assistance is required in order for the exclusion to be applicable. As UNRWA is still providing assistance, Palestinian Refugees as a group are not concerned by the second sentence of Article 1D. Akram's argument would have been more persuasive, had Article 1D excluded persons receiving protection and assistance. Custer has demonstrated that UNRWA has assumed the protection role, and is effectively providing both protection and assistance. ${ }^{38}$ This is also the official position taken by the UNHCR. ${ }^{39}$ The CJEU has confirmed this to be the case in El Kott:

"[i]t is common ground that UNRWA at present constitutes, [...] the only United Nations organ or agency other than the High Commissioner for Refugees which is referred to in the first sentence of article 12 (1)(a) of Directive 2004/83 and in the first subparagraph of article 1D of the Geneva Convention." 40

Following this reasoning, we can reasonably consider that UNRWA's mandate has been broadened to include protection. It is now the sole provider of both assistance and protection for Palestinian Refugees, and is limited in geographical scope, as UNWRA's mandate comprises of Jordan, Syria, Lebanon, the West Bank and the Gaza Strip.

There has been much debate as to when the cessation of protection and assistance, as mentioned in the wording of Article 1D, occurs. It is an important determination to make in

\footnotetext{
${ }^{36}$ Akram (n 5) 42.

${ }^{37}$ Michael Kagan, 'Is there really a protection gap? UNRWA's role vis-a-vis Palestinian Refugees' (2009) 28 Refugee Survey Quarterly 511.

${ }^{38}$ Scott Custer, 'UNRWA: Protection and Assistance to Palestinian Refugees' in Susan M Akram and others (eds) International Law and the Israeli-Palestinian Conflict: a rights based approach to Middle Eastern Peace (Routledge 2011).

${ }^{39}$ UNHCR, Revised Note (n 20).

${ }^{40}$ El Kott (n 3) para 48.
} 
the context of an asylum application, as it determines whether the applicant is concerned by the Article 1D exclusion.

\section{b) Availment of protection and assistance}

In its 2002 Note, the UNHCR underlined that not all Palestinian refugees are registered with UNRWA, and that therefore "the question whether a Palestinian is registered, or is eligible to be registered, with UNRWA will need to be determined individually". ${ }^{41}$ By this statement, the UNHCR acknowledges the difficulties of registration with UNRWA, and recognises that there are refugees who are unable to register. However, it has since changed its position. In the 2009 revised version of the Note, the UNHCR added the following remark: "if the person concerned is inside UNRWA's area of operations, he or she should be considered as 'at present receiving from organs or agencies other than [UNHCR] protection and assistance' within the meaning of paragraph 1 of Article 1D, and hence is excluded from the benefits of the 1951 Convention." 42 This establishes a presumption, which departs from the individualistic approach used in 2002. Kagan suggests this is not a correct application of Article 1D, as the 2009 interpretation constitutes a "group-based" exclusion, whereas the wording of Article 1D mentions persons and not groups. ${ }^{43}$ This seems to run contrary to the ideals in Article 3 of the Geneva Convention, which sets out the principle of nondiscrimination. Kagan sees the UNHCR's newest interpretation as having no basis in the text of the Convention, and notes that the UNHCR itself does not give justifications for its change of position. As argued above, this new reading of the provision sits oddly with the Geneva Convention's aim to adopt an individual, case-by-case approach to refugee recognition.

Therefore, the matter is not only one of entitlement, but also of availment of the protection and assistance provided. It is in the context of the Qualification Directive, complementing the Geneva Convention, that the CJEU has addressed the issue of cessation, in the Bolbol case referred to it by the Office of Immigration and Citizenship of Hungary. As noted above, the Bolbol case preceded El Kott, and whilst Bolbol raised different issues with regard to the interpretation of Article 1D, it answered them only partially - with El Kott providing further answers to those questions. In the Bolbol case before the CJEU, Mrs Bolbol, the applicant, claimed that the second paragraph of Article 1D was applicable to her

\footnotetext{
${ }^{41}$ UNHCR, Note on the Applicability of article 1D of the 1951 Convention relating to the Status of Refugees to Palestinian Refugees (UNHCR 2002).

${ }^{42}$ UNHCR, Revised Note (n 20).

${ }^{43}$ Kagan (n 37).
} 


\section{European and International Law and Palestinian Refugees: Bolbol, El Kott and the Application of Article $1 D$ of the Geneva Convention}

asylum application, and that she should ipso facto benefit from the Convention. Whilst she had not actually availed herself of such protection and assistance, she was entitled to receive it. Furthermore, she claimed cessation had occurred when she left the UNRWA zone of operation in the Gaza Strip, which she claimed was unsafe due to the general climate of violence caused by tensions between Fatah and Hamas. ${ }^{44}$

Three questions were referred to the CJEU. The first was whether the applicant must have availed themselves of the protection and assistance of the agency in order to come under the Article 1D status, or whether it is sufficient simply to be entitled to such protection and assistance. Secondly, the court asked which conditions had to be met in order for cessation to occur and thus bring about the application of the second paragraph of Article 1D. Finally, the court asked whether, once cessation has been proven, the applicant is fully recognised as a refugee, and thus can enjoy the rights contained in the Convention, or whether the additional criteria in $1 \mathrm{~A}(2)$ also have to be met. In answering the first question, the CJEU found that, in order to come within the ambit of Article 1D, one has to avail themselves of protection and assistance. Simple registration is not sufficient. ${ }^{45}$ This view results from the Court's interpretation of the wording of Article 1D, which mentions persons "who are at present receiving protection and assistance". This means that Mrs Bolbol did not come within the exclusion clause of the Qualification Directive. Having chosen this interpretation of the wording, the Court did not find it necessary to address the two further questions. ${ }^{46}$

Thus, the Court restricted the scope of Article 1D to cases where the person is effectively receiving protection and assistance. This narrows down the application of the provision, by choosing to adopt a factual assessment - whether the person is benefiting from protection and assistance - rather than a theoretical one - whether the person is entitled to receive protection and assistance. This reading of Article 1D gives very little protection to Palestinian refugees, as by restricting the application of Article 1D, the Court is also restricting the pool of refugees who can claim the Convention refugee status automatically upon cessation. The Opinion of Advocate General Sharpston in the Bolbol case, delivered on 4 March 2010, highlights the different considerations that she regarded to be relevant in looking at this issue. ${ }^{47}$ She mentions that by adopting an interpretation of Article 1D, which would include all displaced Palestinians, this would give "disproportionately favourable

\footnotetext{
${ }^{44}$ Bolbol (n 2) para 26.

45 ibid, para 53.

46 ibid, para 56.

${ }^{47}$ Case C-31/09 Nawras Bolbol v Bevándorlási és Állampolgársági Hivatal [2010] ECR I-05539, Opinion of AG Sharpston.
} 
treatment for displaced Palestinians at the expense of other genuine applicants for refugee status displaced by other conflicts in the world" 48 . She further argues that, due to Article 1D's exclusionary nature, it should be interpreted in a restrictive manner, rather than in an expansive manner. She also mentions that the "capacity of states to absorb refugees is not infinite". ${ }^{49}$ These considerations, as well as concerns regarding the potential burden on state resources, seem to have influenced the Advocate General's reasoning. Although not explicitly stated in the judgment, these pragmatic concerns may have also had some influence on the Court's reasoning. The Court eventually decided to follow the Opinion.

Therefore, different levels of protection will be granted to Palestinian refugees whether they are living in an UNRWA area, registered with UNRWA, or whether they have availed themselves of protection and assistance. This can be criticised in the sense that the drafters did not intend such distinctions to be made. It is argued that the aim of Article 1D was to provide for a particular refugee population, not create a protection gap for the most vulnerable members of that population; namely those not receiving assistance from the UN. Furthermore, lack of availment of protection and assistance should not be sufficient to exclude Palestinian refugees from UNRWA's mandate. ${ }^{50}$ Takkenberg also takes the opposite view to the Advocate General's and suggests that the debate should not be centred around whether the person is receiving protection and assistance but around their status of registration, and whether it is possible for them to receive assistance. ${ }^{51}$ This would include refugees who reside within the geographical zone covered by UNWRA, but have not availed themselves of its protection or assistance.

Qafisheh and Azarov take a similar approach, and argue that a correct interpretation of Article 1D would be to find that there is no requirement to prove that protection and assistance were received. ${ }^{52}$ Upholding such a requirement would unjustly differentiate between members of the refugee population, thus not ensuring the continuity of protection, which is a concept central to the object and purpose of the Geneva Convention. The UNHCR, in its Note on the Interpretation of Article 1D, adopted the same view. ${ }^{53}$ The Note points out the purpose of Article 1D, which is twofold: to avoid any overlap between competencies, and to ensure the continuity of protection and assistance which is provided to Palestinian

\footnotetext{
48 ibid, para 55 .

49 ibid.

${ }^{50}$ Brenda Goddard, 'UNHCR and the International Protection of Palestinian Refugees' (2009) 28 Refugee Survey Quarterly 475.

${ }^{51}$ Takkenberg (n 15) 101.

${ }^{52}$ Qafisheh and Azarov (n 33) 553.

${ }^{53}$ UNHCR, Revised Note (n 20).
} 


\section{European and International Law and Palestinian Refugees: Bolbol, El Kott and the Application of Article 1D of the Geneva Convention}

refugees. Not recognising those entitled to such protection and assistance as coming within the ambit of Article 1D would deprive them of a status specifically tailored to their situation. The UNHCR strongly recommends that Member States adopt more favourable standards in their interpretation of Article 1D. Goddard is also extremely critical of an interpretation which would seek to differentiate registered and non-registered refugees. ${ }^{54}$ She argues that if this distinction is made, persons who are in similar situations will be treated differently although in fact they fled the same events in 1948.

An important point to bear in mind in looking at availment, as opposed to entitlement, of protection and assistance is that UNRWA has long been criticised for its registration and eligibility procedure, which is not open to all. Eligibility for UNRWA works with a registration system - where the status of being eligible for UNRWA is passed down from parents to their children. However, only recently, pursuant to UNRWA's revised Eligibility Instructions, ${ }^{55}$ does this status pass down through mothers as well as fathers. Prior to this, a child's father had to be registered in order for the child to be eligible for registration with UNRWA. Thus, the child of a registered mother is now eligible for UNRWA protection, regardless of whether his or her father is registered.

This practice highlights the difficulties one can encounter in trying to obtain protection and assistance from the Agency, something which becomes important when looking at the interpretation of Article 1D. The criteria for registration, along with the Bolbol judgment, create a multitude of distinctions, all of which can entail different forms of protection for individuals who are in very similar situations. The application of Article 1D should not be restricted to those registered with UNRWA. Such a discriminatory interpretation and application of the Geneva Convention does not seem compatible with the overall aims of the Convention.

\section{c) Cessation of protection and assistance}

Article 1D was set up as an exclusion, albeit temporary, to refugee status. Therefore, pinpointing cessation will help to identify whether one is concerned by the suspension clause or not. The intention of the drafters was to ensure that Palestinian refugees would not be left without protection, should the Agency ever cease to exist. At the time of drafting, there was no way to anticipate the soar of international travel. Any refugees that had sufficient funds to travel to another region could clearly support themselves, and would not be a burden on the

\footnotetext{
${ }^{54}$ Goddard (n 50).

${ }^{55}$ UNRWA, Consolidated Eligibility and Registration Instructions (UNWRA 2009).
} 
host state. As such, any influx of refugees coming under the second paragraph of Article 1D would have been of minor concern, as it is submitted that the drafters did not think they had to provide for the situation where Palestinian refugees had the possibility of leaving the refugee camps. Although the drafters' intentions were to address a situation where the UN Agencies would cease to exist, there is nothing in the language to restrict the cessation to a scenario that must affect all Palestinian refugees. Adopting an evolutionary interpretation of the Convention, Takkenberg argues that we should take a case-by-case approach to cessation. ${ }^{56}$ Advocate General Sharpston also adopts this reading in her Opinion in the Bolbol case, and points out that if cessation only referred to a total cessation of UNRWA, thus affecting the whole population of refugees, then the second sentence of Article 1D would have yet to apply to any refugee. ${ }^{57}$ Furthermore, the term "for any reason" suggests that there is a multitude of events that can cause cessation.

Therefore, there is strong authority to suggest that cessation, for the purposes of Article 1D, includes a departure from the UNRWA zone of operations. Qafisheh and Azarov, in their commentary of the Geneva Convention, argue that nothing in the wording of the Article excludes a voluntary departure from UNRWA zone of operations. ${ }^{58}$ They put forward multiple arguments to support this view. First, it reflects the plain language of the provision, which does not mention the possibility of return as a requirement for cessation to occur. Secondly, Article 1D is meant to ensure heightened international protection for Palestinian refugees, and aims to recognise refugees as exercising agency, not simply being passive subjects. Recognising that voluntary departure may lead to cessation of the exclusion ground would certainly be compatible with such aim. Finally, they mention that a restrictive interpretation would place an excessive burden of proof on the applicant, something which goes against the idea of international protection promoted by the Convention. Whilst these arguments are convincing, they seem to revolve around the general object and intent of the Convention. However, the Geneva Convention, as mentioned above, has had to adapt in light of an ever-changing international context, and it is thus difficult to continuously rely on the intention of the drafters. Furthermore, it is highly unlikely that states will go as far as recognising that any Palestinian refugee can benefit from the Convention, following their voluntary departure from the UNRWA zone of operations. They are reluctant to do this, as it would amount to an invitation for the Palestinian refugee populations to seek asylum in their

\footnotetext{
56 Takkenberg (n 15) 107.

${ }^{57}$ Bolbol, Opinion of AG Sharpston (n 47) para 79.

${ }^{58}$ Qafisheh and Azarov (n 33) 561.
} 


\section{European and International Law and Palestinian Refugees: Bolbol, El Kott and the Application of Article 1D of the Geneva Convention}

territory. Finally, recognising refugees as exercising agency does not fit in with states' view of refugee law, which remains State-centric and is built on an outdated notion of refugees not exercising agency.

Many states look to the concept of returnability in identifying cessation, as has been done by courts in Finland, ${ }^{59}$ as well as legislation in the Netherlands. ${ }^{60}$ The idea is to look at whether there is a possibility for the applicant to return to the place of origin. If such a possibility exists, then cessation will not have occurred, and Article 1D will still apply. On the other hand, if there is no possibility of return and the refugee has not left of his own accord, then cessation will be deemed to have occurred. Takkenberg has also argued that the term "for any reason" does not include a voluntary departure of UNRWA's area of operations. ${ }^{61}$ Similarly to the concept of returnability, he recognises that cessation may occur where refugees are outside of the UNWRA mandated zone, only if they cannot return to the territory of habitual residence. This could be the case when there is no possibility of return, or where the applicant refuses to return because of a danger or threat to him. The UNHCR Revised Statement also sheds some light on this approach to the concept of returnability; situations falling into this scenario include: where the applicant is unable to return, for instance where the authorities will not let him into the territory, will not renew travel documents; or where the applicant is unwilling to return due to a threat to his or her physical safety or freedom. ${ }^{62}$

This position echoes the view that was taken by the CJEU in the El Kott case, the facts of which were as follows: three Palestinian men, who resided in refugee camps run by UNRWA in Lebanon, were forced to flee following threats to their safety. Upon arrival in Hungary, they applied for refugee status, which was not granted to them. They appealed the decision, and the national court referred the matter to the CJEU in the context of the Qualification Directive. In the judgment, the CJEU first reiterated that mere voluntary departure from the zone of operations does not amount to cessation, contrary to what Qafisheh and Azarov argue. ${ }^{63}$ This is a sensible deduction in light of the EU Directive, as there would be no need for Article 12(1)(a) of the Qualification Directive, which reiterates the wording of Article 1D, if the latter were never applicable outside of the UNRWA zone of

\footnotetext{
${ }^{59}$ Finland Supreme Administrative Court, Supreme Administrative Court Decision of 31 October 2002. KHO: 2002:69, 31 Oct 2002.

${ }^{60}$ Aliens Circular C1 of the Dutch Minister of Alien Affairs and Integration.

61 Takkenberg (n 15) 107.

${ }^{62}$ UNHCR, Revised Statement on Article 1D of the 1951 Convention (UNHCR 2009).

${ }^{63}$ El Kott (n 3) para 49.
} 
operations. It went on to identify three situations where cessation could occur. They are: where the agency ceases to exist, where the agency is unable to fulfil its mandate, or where the person had to leave the zone of operation for reasons beyond their control. ${ }^{64}$ Therefore, the judgment does show a willingness to recognise that cessation "for any reason" may include leaving the zone of UNRWA operations, if this is done for reasons beyond a person's will or control. The Court suggests it is willing to recognise cessation, if the refugee can show that his or her "personal safety is at serious risk" and it is "impossible for the agency to guarantee his living conditions." 65 The Court ultimately leaves it up to the host state to carry out an assessment of risk, and consider whether risk in the refugee camp is sufficient for the decision to leave to be considered independent of any volition. The national courts will have to assess, on a case-by-case basis, first whether a sufficient threat exists to the applicant's safety, and secondly whether UNRWA is unable to guarantee living conditions, in line with its mandate. This position and wording broadly reflects that of the UNHCR, who in the Note on the Interpretation of Article 1D identified two main instances of cessation: "threats to life, security, freedom or other protection related reasons", and "practical, legal and safety barriers to return". ${ }^{66}$ The Court has set a low threshold, and developed a test centred around the personal safety of refugees, which is appreciable. However, the effect of the judgment will boil down to how national courts carry out the assessment. It will highlight the difficulties that courts face in appreciating a situation of general risk, and in carrying out an impartial assessment.

\section{POST-EL KOTT ASSESSMENT OF RISK IN REFUGEE CAMPS BY NATIONAL COURTS}

As argued above, the outcome of the El Kott judgment is that Palestinian refugees will be able to prove cessation if they cannot return to their country of habitual residence due to reasons beyond their control, and if the organ or agency mandated to provide them with protection cannot guarantee their living conditions. Whilst national courts have often come to assess risk when considering refugee claims based on Article 1A(2) of the Geneva Convention, it is a specific assessment in light of the individual circumstances of the claimant, rather than a general appreciation of the situation in the country or origin. Therefore, in the context of a post-El Kott refugee application, an applicant for refugee status

\footnotetext{
64 ibid, para 65.

65 ibid, para 63.

${ }^{66}$ UNHCR, Revised Note (n 20).
} 


\section{European and International Law and Palestinian Refugees: Bolbol, El Kott and the Application of Article $1 D$ of the Geneva Convention}

in the European Union, having proven that he or she has received protection and assistance from UNRWA, will see the court scrutinise the threat to life and personal safety in the context of the widespread violence. Assessing indiscriminate violence is a difficult task for courts. It is complicated to appreciate how indiscriminate the level of violence is. Furthermore, reliable information sources in zones of such conflict must be found. Whilst statistics may be useful, it is difficult to appreciate the situation based solely on numbers.

In light of the guidance offered by the CJEU in El Kott, it is useful to highlight the difficulties of risk assessment in the context of refugee protection. With the mechanism of subsidiary protection, EU law complements the Geneva Convention. Subsidiary protection is a status created by the Qualification Directive. Its purpose is to apply in the situation where the asylum seeker does not qualify for refugee status, but nevertheless cannot be sent back to his or her country of origin, due to risk of "serious harm" in the country of origin. This includes situations of indiscriminate violence, exposure to or risk of death penalty, torture, or inhuman or degrading treatment, as set out in Article 15 of the Directive. It is thus a form of protection which is completely separate from the protection granted to a refugee under Article 1(A)(2) or Article 1D. In El Kott, in the context of article 1D, the Court spoke of "personal safety at serious risk" ${ }^{\text {, }}$, whilst subsidiary protection is granted where there is a "serious and individual threat to a civilian's life". ${ }^{68}$ Both subsidiary protection and Article 1D seek to address the situation of applicants who do not come within the scope of the Convention. Furthermore, they address situations of general violence, rather than focusing, as Article $1 \mathrm{~A}(2)$ of the Geneva Convention does, on completely individualised threats. Therefore, the El Kott judgment brings up the same interpretative difficulties as the ones brought about by subsidiary protection:

\footnotetext{
${ }^{67}$ El Kott (n 3) para 63.

${ }^{68}$ Council Directive 2011/95/EC of 13 December 2011 on standards for the qualification of third-country nationals or stateless persons as beneficiaries of international protection, for a uniform status for refugees or for persons eligible for subsidiary protection, and for the content of the protection granted (recast) [2011] OJ L337/9.
} 


\section{The CJEU and the European Court of Human Right's Assessment of Violence in} the Context of Subsidiary Protection

a) Elgafaji and national court interpretation of level of violence and individualisation of risk

In the Elgafaji case, ${ }^{69}$ the CJEU was asked to elaborate the criteria to be used when determining whether an applicant is eligible for subsidiary protection under Article 15(c) of the Qualification Directive. The wording of Article 15(c), which mentions "serious and individual threat to a civilian's life" in the context of "indiscriminate violence." Prior to Elgafaji, there was much confusion as to the purpose of Article 15(c), and whether it was really distinct from Article 15(a) and 15(b), which address two different types of harm death penalty or execution, and torture, inhumane or degrading treatment. The Court in its judgment sought to clarify the wording of Article 15. It seems difficult to reconcile indiscriminate violence with the idea that certain individuals are being more targeted than others. Nevertheless, this is what is suggested in the wording of the provision.

\section{i) Threshold of indiscriminate violence}

As regards the level and nature of indiscriminate violence, which is required, national courts have used other international norms in order to assess the level of risk in the applicant's country of origin. German courts in particular have supplemented the Elgafaji case law using international humanitarian law. ${ }^{70}$ In Elgafaji, the CJEU does not address this issue, and leaves the determination of the existence of a conflict up to national courts, without referring to humanitarian norms.

A brief look at the case law of national courts shows that the latter often intertwine the notion of indiscriminate violence and that of armed conflict. One particular case before the German Federal Administrative Court was that of an individual of the Sunni faith, residing in Iraq, who felt threatened and feared for his life. ${ }^{71}$ The Higher Administrative Court of Germany, in examining his appeal, found that the situation of danger in Mosul, the applicant's city of origin, despite the frequency and magnitude of terrorist attacks, was not "so great that practically any civilian was exposed to a serious individual danger merely because of his or her presence in the region concerned" ${ }^{72}$ In this case, the Federal Court confirmed the Higher

\footnotetext{
${ }^{69}$ Case C-465/07 Meki Elgafaji and Noor Elgafaji v Staatssecretaris van Justitie [2009] ECR I-00921.

${ }^{70}$ German Federal Administrative Court BVerwG 10C 13.10 (17 November 2011) 24(3) International Journal of Refugee Law 603; German Federal Administrative Court BVerwG 10C 43.07 (24 June 2008).

${ }^{71}$ BVerwG 10C 13.10 (n 70).

72 ibid.
} 


\section{European and International Law and Palestinian Refugees: Bolbol, El Kott and the Application of Article 1D of the Geneva Convention}

Administrative Court's finding that "no nationwide internal armed conflict was present in Iraq". ${ }^{73}$ Throughout the judgment, the Court focuses on the density of the conflict. The distinction is made between a high level of indiscriminate violence, and a level of violence so exceptionally high that any person present is at risk. In the first scenario, the Court applies the Elgafaji interpretation and finds that you need circumstances to intensify the risk. However, in cases of exceptional violence, then there is no need to prove such circumstances, as also deduced in Elgafaji. The Court qualifies the latter situation as an exception, further showing the reluctance of courts to open up the category of persons eligible for subsidiary protection.

In this case, the Federal Administrative Court carried out a very detailed analysis to assess the risk in the country of origin. In the judgment, it is apparent that the Court relied on statistics to make the decision, coming to the conclusion that there was a $0.12 \%$ chance of the applicant being injured or killed by a terrorist attack in the Nineveh Province. ${ }^{74}$ It also identified the "high level of indiscriminate violence" required in order to meet the conditions of subsidiary protection. This highly detailed quantitative analysis seems unbecoming in the context of an appreciation of generalised violence. It bypasses other key factors that cannot be translated into statistics, such as severity of injuries, whether the violence is widespread or localised, and the availability of medical care. The UK Upper tribunal has taken a different approach, and held in a case from 2010 that "evidence cannot be confined to the numbers of casualties", ${ }^{75}$ although appreciating that statistics may "furnish a part of the overall evidence needed to assess $15(\mathrm{c}) "{ }^{\prime}{ }^{76}$

In another German case, the Court found that in the situation where the applicant would face a serious and individual threat "solely on account of his presence on the territory of that country or region", ${ }^{77}$ this would amount to a situation of internal conflict under the meaning of Article 15(c) of the Qualification Directive, which is to be interpreted in light of the 1949 Geneva Conventions and Additional Protocol II. ${ }^{78}$ Whilst there is no definition of internal conflict in the Geneva Conventions, the Additional Protocol II, which applies in noninternational armed conflict, suggests that it is more than simply "situations of internal disturbances and tensions, such as riots, isolated and sporadic acts of violence"79. It seems a

\footnotetext{
73 ibid, para 4.

74 ibid, para 7.

${ }^{75}$ HM and Others [2010] UKUT 331 para 76.

76 ibid, para 258.

${ }^{77}$ German case 10C 43.07 (n 70).

${ }^{78}$ German case 10C 43.07 (n 70) para 37.

79 Additional Protocol to the Geneva Conventions of 12 August 1949, and relating to the Protection of Victims of Non-International Armed Conflict (8 June 1977) article 1(2).
} 
high threshold of violence is required. Although the German Court's attempt at finding objective standards against which risk can be measured, be it statistics or norms of international law, can be useful, it sets a high threshold for applicants, and is insufficient in its focus on protection of the individual. The Czech Republic has also adopted this approach, and has considered that a conflict which satisfies the standard of internal armed conflict, as set out by the International Criminal Tribunal for the former Yugoslavia (ICTY), in the Tadič case $^{80}$ could be an internal conflict for the purposes of Article 15(c). ${ }^{81}$ The Tadič standard is broader than the definition contained in the Additional Protocols, as it refers to "protracted armed violence between governmental authorities and organized armed groups or between such groups within a State" ${ }^{\prime 2}$. The Tadič definition may prove useful, as it includes violence between armed groups in its understanding of internal conflict. In a more extreme example, a 2008 case from the UK Asylum and Immigration Appeals Tribunal, ${ }^{83}$ the Tribunal chose to define "indiscriminate violence" by referring exclusively to international humanitarian law. It considers that the purpose of Article 15(c) is to protect individuals from serious violations of international humanitarian law, and therefore interprets 'indiscriminate violence' as referring to those violations only. The Tribunal concludes that the notion of "indiscriminate violence" should not be construed to cover "purely criminal" 84 or "non-military" 85 violence.

Whilst it is appreciable to have an objective recognised standard of the threshold of violence required, international humanitarian law should be used carefully in the context of subsidiary protection. It must be highlighted that the purpose of international humanitarian law is to ensure the protection of civilians in a situation of conflict. Refugee law applies to persons who find themselves in a very different situation, as they are no longer within the conflict zone. Furthermore, humanitarian law seeks to apply to the parties to the conflict, in regulating their conduct. It is thus difficult to rely solely on a humanitarian law interpretation of the wording used, as is done in the $K H$ case. McAdam emphasises that whilst different sources should influence the determination of an internal and international armed conflict, the difference in purpose between international humanitarian law and Article 15(c), which aims

\footnotetext{
${ }^{80}$ Case No IT-94-1-T Tadič [1991] International Criminal Tribunal for the former Yugoslavia.

${ }^{81}$ Supreme Administrative Court of the Czech Republic [2009] no 5 Azs/28/2008.

82 Tadič (n 80) para 70.

${ }^{83} \mathrm{KH}$ (Article 15(c) Qualification Directive) Iraq v Secretary of State for the Home Department [2008] UKAIT 00023.

${ }^{84}$ ibid, para 95 .

85 ibid.
} 


\section{European and International Law and Palestinian Refugees: Bolbol, El Kott and the Application of Article $1 D$ of the Geneva Convention}

to grant protection, should not be overlooked. ${ }^{86}$ The UNHCR also takes this position in its 2008 Statement on Subsidiary Protection, and makes it clear that "international protection needs arising from indiscriminate violence are not limited to situations of declared war or internationally recognized conflicts" 87

The divergent approaches taken in these cases raise questions about the need for a fixed standard of violence. Adopting a restrictive interpretation of international and internal armed conflict, based on existing international norms, it is submitted, also creates the possibility of another protection gap emerging. Whilst using humanitarian law in the context of risk assessments can be seen as an opportunity to have a more consistent application of the Directive, by ensuring an objective standard exists, it should be limited to informing the assessment, and not setting a fixed standard. This would have the consequence of restricting the scope of application of the measure.

ii) The individualisation of risk:

The Court in Elgafaji was adamant in confirming that Article 15(c) was distinct from Article 15(a) and 15(b), in that the latter are concerned with a "particular type of harm", whereas Article 15(c) covers a "general risk of harm". ${ }^{88}$ Thus, Article 15(c) refers to a threat, rather than specific acts. However, the Court did feel it was necessary to read Article 15 as a coherent whole. Articles 15(a) and 15(b) both focus on the individual circumstances of the applicant, which is why the Court deduced that some degree of individualisation was also required for Article $15(\mathrm{c}) .{ }^{89}$ It is at this point in the reasoning that the sliding scale of indiscriminate violence is introduced, which is an attempt by the Court to reconcile the notion of "individual threat" with that of "indiscriminate violence". The Court thus presents the assessment of risk under Article 15(c) as a scale: the more the applicant can show that he or she is individually targeted by the violence, the lower the level of indiscriminate violence required. ${ }^{90}$ The judgment specifies that "indiscriminate violence" is indiscriminate in that it goes beyond people's personal circumstances. However, the "serious and individual threat" to be shown by the applicant implies that the risk is higher than it would be for the average person, for that particular applicant. Thus, where the applicant would, "solely on account of

\footnotetext{
${ }^{86}$ Jane McAdam, 'Individual Risk, Armed Conflict and the Standard of Proof in Complementary Protection Claims' in James C Simeon (ed), Critical Issues in International Refugee Law (CUP 2010).

${ }^{87}$ UNHCR, UNHCR statement on Subsidiary Protection under the EC Qualification Directive for People Threatened by Indiscriminate Violence (UNHCR 2008) 6.

${ }^{88}$ Elgafaji (n 69) para 32.

89 ibid, para 38.

${ }^{90}$ ibid, para 39.
} 
his presence on the territory of that country or region, face a real risk of being subject to the serious threat referred in article 15(c) of the Directive"91, then there is no need to show distinguishing features proving such a threat. However, when the situation is not one of total conflict, such features must be shown, in order to establish that the applicant is targeted. ${ }^{92}$

Regarding the individualisation of the risk, as required following Elgafaji, national courts have interpreted the judgment in varying ways. For instance, the Swedish Migration Board held that the applicant had to be "personally at risk", due to "particular circumstances". ${ }^{93}$ German courts have interpreted the individual risk requirement to mean that the applicant must simply be at a "greater risk" than the general population, due to distinguishing features - such as exercising certain professions, or having particular religious or ethnic affiliations. ${ }^{94}$ The different wording used shows the nuanced ways in which the CJEU's judgment may be applied to facts. Hathaway strongly criticises the idea that any appreciation of risk should be individualised: "to require a singling out confuses the requirement to assess risk on the basis of the applicant's particular circumstances with some erroneous notion that refugee status must be based on a completely personalised set of facts." ${ }^{95}$ Errera also suggests that the task ahead for national courts is to focus on risky situations, rather than personal experiences. ${ }^{96}$ McAdam suggests that we should focus on whether there is a reasonable chance that the applicant will suffer serious harm, rather than linger on the interpretation of the word "individual", ${ }^{97}$ as used in the Qualification Directive. McAdam further highlights the difficulties which are presented by Article 15(c), and concludes that inconsistent application by national courts has led to legal uncertainty regarding Article 15(c). This inconsistent interpretation and application of the case law amongst Member States will necessarily come at a disadvantage for applicants, who will have no certainty as to which test will be applied. She argues that, in placing too much emphasis on the notion of "individual" risk, there is a risk that the burden on the applicant will become too great, thus rendering subsidiary protection ineffective as a complementary mechanism of protection. ${ }^{98}$

\footnotetext{
${ }^{91}$ ibid, para 35.

92 ibid para 39.

${ }^{93}$ Swedish Migration Board, Lifos dokumentnr 16852, beslut (5 July 2007).

94 German case 10C 13.10 (n 70).

95 James C Hathaway, The Law of Refugee Status (Butterworths 1991) 91-92.

96 Roger Errera, 'The CJEU and Subsidiary Protection: Reflections on Elgafaji - and After' (2011) 23(1) International Journal of Refugee Law 93.

${ }^{97}$ McAdam (n 86) 68.

98 ibid, 67.
} 


\section{European and International Law and Palestinian Refugees: Bolbol, El Kott and the Application of Article $1 D$ of the Geneva Convention}

Elgafaji has provided some much-needed clarification to national courts on Article 15(c). However, many commentators feel that the Court could have gone further. Errera has qualified the judgment as being a missed opportunity, as it provided little guidance to national courts. ${ }^{99}$ The sliding scale of indiscriminate violence is ambiguous and difficult to apply to facts. The divergent approaches and interpretations adopted by national courts have been highlighted above. Furthermore, there lies a danger in relying on the requirement of "distinguishing features". Although courts have been relying on a restrictive interpretation of this requirement in order to restrict flows of refugees, it dangerously echoes the requirement for a ground of persecution, as required under Article 1A(2) of the Convention. As confirmed by the UNHCR Statement, complementary protection mechanisms such as subsidiary protection should only be envisaged "after full use has been made of the 1951 Convention". ${ }^{100}$ Therefore, their use and development by national courts should seek to complement and maximize the opportunities for providing international protection. It is argued that placing too great a burden on the applicant to show distinguishing features in the context of indiscriminate violence undermines this. This would be all the more worrying if applied in the context of Article 1D, as the provision seeks to establish a more favourable regime for a refugee population. If the assessment carried out resembles that of Article $1(\mathrm{~A})(2)$, the provision loses its purpose.

\section{b) European Court of Human Right's assessment of generalised violence}

The European Court of Human Rights (ECtHR) also took a position on indiscriminate violence in Sufi and Elmi ${ }^{101}$ - in which it gave its own set of criteria for the threshold of indiscriminate violence expected. It is important to bear in mind that Sufi and Elmi was a case before the European Court of Human Rights, and the judgment was therefore based on Article 3 of the European Convention on Human Rights (ECHR), which prohibits torture and inhumane treatment. Due to Article 3's non derogable nature, states that have signed up to the ECHR cannot send an applicant back to where there is a real risk he may be tortured. ${ }^{102}$ The judgment addresses the relationship between Article 3 of the ECHR and Article 15 of the

\footnotetext{
${ }^{99}$ Errera (n 96) 101.

${ }^{100}$ UNHCR, Revised Statement (n 62) 4.

${ }^{101}$ Sufi and Elmi v UK (2011) ECHR 1045.

102 Jane McAdam, Complementary Protection in International Refugee Law (OUP 2007) ch 4; Guy GoodwinGill and Jane McAdam, The Refugee in International Law (3rd edn, OUP 2007) ch 6; with regard to situations of general violence, see Ahmed v UK (1996) ECHR 1996.
} 
Qualification Directive. Therefore, whilst it is not directly binding on Member States in the context of the Qualification Directive, it may prove influential.

In order to appreciate the situation, the ECtHR looks at the "general situation", as well as the situation of different regions where the applicants could be expected to relocate. ${ }^{103}$ The judgment identifies a yardstick, which includes assessing the methods of warfare used, whether they increase the possibility of civilian casualties, the extent to which such methods of warfare are used, and the location of the fighting, whether it is widespread or confined to one area. ${ }^{104}$ The Court also distinguishes between on the one hand, a "dire humanitarian situation" which is attributable to poverty and general lack of resources, and on the other a humanitarian crisis caused by the actions of the parties to the conflict. ${ }^{105}$ There is extensive description of the situation, and the ECtHR draws on reports from a wide range of sources, including reports from the UK and the US. Whilst the decision is also based on UN reports and estimates, the court does provide for a margin of error in these numbers. ${ }^{106}$ The Court also stated that, in carrying out an assessment of the situation in the country of origin, national courts may take into account the geographic extent of the conflict, and the destination of return for the applicant. However, for the purposes of the Palestinian refugees, that is of limited concern, as they will often lack the documentation to go anywhere but the UNRWA zones, for which there is precise delimitation.

The ECtHR's detailed assessment - in particular the variety of information used and the range of sources referred to - is useful and instructive, whilst providing for inaccuracy and human error. Whilst national courts have used a variety of sources, their approach remains heterogeneous. In this context, the ECtHR assessment may prove useful in the context of risk assessments with regard to situations of indiscriminate violence. The approach of the ECtHR is balanced, informed and pragmatic, qualities that are not found in the CJEU judgements regarding Article 1D, which remain vague and do not delve into the intricacies of carrying out risk assessments.

\section{Level of Violence in UNRWA Refugee Camps}

In applying the El Kott test to Palestinian Refugees, courts will have to assess whether cessation of protection and assistance from UNWRA has occurred for reasons beyond the

\footnotetext{
${ }^{103}$ Sufi and Elmi (n 101) para 216.

104 ibid, para 241.

105 ibid, para 282.

106 ibid, para 119.
} 


\section{European and International Law and Palestinian Refugees: Bolbol, El Kott and the Application of Article $1 D$ of the Geneva Convention}

control of the individual. In other words, courts will have to assess whether the situations in UNWRA zones and refugee camps amount to the standard of violence set out by the CJEU.

Refugee camps face constant problems of gender-based violence. A UNHCR Report on gender based-violence highlights the danger faced by women and girls in their everyday lives. ${ }^{107}$ The report holds the causes to be the corruption of guards and patrol officers within the camps, as well as the disruption of social structures due to the constant flow of arrivals. Such arrivals make it difficult to establish and maintain order in the camps. Refugee Camps are also directly affected by the regional political climate. For instance, the Palestinian Refugee Camps in Lebanon are dreading renewed violence as tensions between Hamas and Hezbollah are rising. ${ }^{108}$

In the case of Sufi and Elmi, as mentioned above, the European Court of Human Rights explicitly recognises the dangerous situation of certain refugee and Internally Displaced Persons camps, such as those in the Afgooye Corridor, or the Dadaab camps in Kenya. ${ }^{109}$ The Court goes on to consider that should the applicant be sent back there, "there would be a real risk that he would be exposed to treatment in breach of Article 3 on account of the humanitarian conditions there". ${ }^{110}$ In assessing situations, the judgment points to factors such as nutrition, hygiene, shelter, violence and the expected duration of the situation. In other words, the ECtHR has no difficulty in recognising that the situation of certain refugee camps is particularly violent.

The precarious and unstable situation of refugee populations is conducive to outbursts of generalised violence, a recurring problem in refugee camps. Militarisation and genderbased violence in particular are of significant concern to the international community. ${ }^{111}$ Therefore, we can be relatively certain that the situation in Palestinian refugee camps, if correctly assessed by national courts, has the potential to satisfy the El Kott requirement of violence. However, that it will satisfy the upper end of the scale, a level of such violence that one's presence constitutes a sufficient threat, is far from being a given. Therefore, if national courts uphold a requirement of distinguishing features, it will constitute yet another hurdle for Palestinian refugees' asylum applications, bringing it closer to the requirements set out in

\footnotetext{
${ }^{107}$ UNHCR, Sexual and Gender-based Violence against Refugees, Returnees and Internally Displaced Persons (UNHCR 2003).

${ }^{108}$ Elie Ferzli, 'Hamas Fears Renewed Violence in Palestinian Refugee Camps' (Al Monitor, 13 June 2013) <www.al-monitor.com/pulse/security/2013/06/hamas-fears-violence-hezbollah-lebanon-refugee-camps.html> accessed 12 May 2014.

109 Sufi and Elmi (n 101) para 60.

110 ibid, para 296.

${ }^{111}$ UNHCR, Sexual and Gender-based Violence (n 107).
} 
Article 1(A)(2), and therefore denying them of the protection the drafters intended them to receive.

\section{E. CONCLUSION}

The CJEU's recent standpoint on the interpretation of Article 1D has allowed for the possibility of a harmonisation of the asylum policy regarding Palestinian Refugees. In Bolbol, the Court held that, in order to come under the second paragraph of Article 1D, refugees had to avail themselves of UNRWA aid. In El Kott, the Court confirmed that, once cessation had been proven, refugees would automatically benefit from the Convention status, without having to satisfy further requirements. The El Kott judgment also recognised that nonreturnability to the UNRWA zone of operations could be recognised where there is a serious threat to the applicant's life.

Yet, the high hopes that were vested in the CJEU's opportunity to review the application of the Geneva Convention were not completely fulfilled. Whilst the CJEU in $E l$ Kott makes it clear that, where the applicant's personal safety is at risk, he or she should automatically benefit from refugee status under the Convention, it has given little guidance to national courts in terms of how to carry out an assessment of the situation in refugee camps. It may have done this purposely, to allow them a certain leeway. Member States are conscious of the fact that recognising a general climate of violence, without such a requirement for individual risk, would amount to prima facie refugee recognition, therefore creating an incentive for a huge number of refugees to seek asylum in their territory. This may lead, as it has in the context of subsidiary protection, to inconsistent refugee recognition across different Member States. In order to achieve consistent refugee recognition, it is vital that the CJEU give adequate guidance to the Member States.

There are several other lessons that we can learn from the case law that has developed regarding assessment of generalised violence by the CJEU. In the assessment of the general risk in refugee camps, a notion of indiscriminate violence, informed by international humanitarian law, and using standards such as the one set out in Tadič, would best serve the interests of the Palestinian Refugee population. However, whilst these norms should inform the risk assessment as carried out by the Court, they should not be taken as a fixed benchmark, as this would result in a protection gap, as argued.

The statement from European states during the drafting of the Geneva Convention, which highlights their reluctance to "bind themselves to a text under which their obligations 
would be extended to include a new, large group of refugees"112 is still true today. This is why the CJEU's activism is crucial, in order for the Geneva Convention to be consistently applied, in accordance with its purpose and object. It remains to be seen whether the CJEU judgments will have weight outside of the EU. The wording of Article 1D and that used in the Qualification Directive being almost identical, it is likely that it will have a bearing on other jurisdictions' interpretation of this provision.

${ }^{112}$ Statement of Mr Rochefort (France) (26 November 1951) UN Doc A/CONF.2/SR.19 11. 